\title{
Relationship of pollution with distribution of Mermaid's tresses (Spirogyra) in different localities of river Kabul
}

Khushnood ur Rehman ${ }^{1}$, Izaz Khuram ${ }^{2}$, Tabassum Yaseen ${ }^{3}$, Laila Farooq $^{1}$ and Sher Wali ${ }^{*}$

1. Department of Botany, Islamia College, Peshawar-Pakistan

2. Department of Botany, University of Peshawar-Pakistan

3. Department of Botany, Bacha Khan University, Charsadda-Pakistan

*Corresponding author's email: sherwali@icp.edu.pk

Citation

Khushnood ur Rehman, Izaz Khuram, Tabassum Yaseen, Laila Farooq and Sher Wali. Relationship of pollution with distribution of Mermaid's tresses (Spirogyra) in different localities of river Kabul. Pure and Applied Biology. Vol. 8, Issue 4, pp2128-2134. http://dx.doi.org/10.19045/bspab.2019.80157

\begin{tabular}{llll}
\hline \hline Received: 09/05/2019 & Revised: 15/07/2019 & Accepted: 23/07/2019 & Online First: 04/08/2019 \\
\hline \hline
\end{tabular}

\section{Abstract}

The current research work focused on the distribution of Spirogyra in different localities of river Kabul in relation to pollution. Species' diversity was determined from water polluted due to all the three types of water pollution i.e. domestic, industrial and agricultural pollution. In all the sets of collected samples from the research sites a total of 37 species of Spirogyra belonging to class Chlorophyta were recorded. Of them 30 species were collected from unpolluted, 36 from slightly polluted and 4 from highly polluted waters. The chemical analysis of collected water samples from three selected sites showed high concentration of $\mathrm{CaCO}_{3}(245 \mathrm{mg} / \mathrm{L})$ at highly polluted site Main Gujar; $188 \mathrm{mg} / \mathrm{L}$ and $164 \mathrm{mg} / \mathrm{L}$ at Khazana and Shah Alam respectively.

Keywords: Algae; Mermaid Tresses; Pollution; River Kabul; Spirogyra

\section{Introduction}

The River Kabul is actually the River Chitral that emerges from Chitral flows into Afghanistan and comes back to Peshawar [1]. It enters in to Pakistan through Shalman, then reaches to Warsak Dam while then it divides into several branches which flow in several sites of Peshawar valley for irrigating a major area. There are three branches of River Kabul, one is Shah Alam, second is Naguman and third one is Adezai. [2] Described that Naguman and Adezai branches are unpolluted. Mainly the unpolluted water is present in Serdaryab, Naguman and Shah
Alam up to Muhajer Camp. Khazana has slightly while at Main Gujar water is highly polluted. The River is used for waste material dumping and therefore is very polluted and turbid [3]. Algae are very diverse group almost found in every habitat from marine ecosystem to fresh water bodies, brackish water and moist habitat. Algae have a great importance to life on earth $[4,5]$. Micro-algae are the first precursor in the food chain for the aquatic animals and hence play an excellent role of primary producers in aquatic habitats. Algae have both the beneficial and harmful impacts [6]. They cause troubles by trapping 
into the propeller of boats and produce eutrophication [7]. In spite the negative impacts algae also use in the water cleaning and determination of pollution [8]. Freshwater algae are widely used in ecological assessment and monitoring of water quality [9]. Green algae are one of the most diverse groups of Protista [10, 11], which shows diverse morphological structures i.e. unicellular, flagellated, unflagellated, colonial, coccoid, branched or unbranched filamentous with approximately six hundred (600) genera and ten thousand $(10,000)$ species. They are cosmopolitan and found almost in every habitat from poles regions to deep seas, freshwater ponds, pools as well as in terrestrials regions [10]. Freshwater algae are very diverse organisms that occupied all natural environments where the water and light are present. Algae of aquatic habitats have a definite answer to changes in the water properties and, thus, are widely used as bio-indicators of water quality and ecosystem status $[12,13,14]$. The algae is living organisms and are having a short span of life, its flora will also increase day by day such in ditches and/or moorland, Zygnemataceae algae, particularly Spirogyra, is the example of floating algae and 47 species were recorded in ditches and pools [15]. Sixty (60) species of the genus Spirogyra were recorded in the United Kingdom, specifically Netherlands [16]. After all it has been observed the there is always greater number of the algal species where there is low pollution at site of the rivers, ponds and sea. Such as in hard water ditches, Spirogyra forms a abundantly diversified species with approx 20 species per each site. While at very low basic and very week acidic sites, the number of algal species per each site is significantly decreasing, whereas under highly acidic $(\mathrm{pH}$ $<5$ ), the Spirogyra does not exists and is replaced by some other algae like, (Mougeotia, Zygnema, Klebsormidium, Microspora etc). In spite of Spirogyra most of the algal species have wide range of existences; like in different environmental conditions twenty two (22) species were existed in the above said habitats, however, majority of the species are not existed in that conditions [17].

\section{Materials and methods}

To assess the Spirogyra diversity and ecology of the Kabul River, three research sites were selected in the Peshawar Valley. The sites included highly polluted (a), slightly polluted (b) and unpolluted (c) (Figure 1). Sampling was carried out during the autumn and spring seasons in 2017-2018. At each site, samples were collected from different habitats containing Spirogyra. The samples were brought into the laboratory, Department of Botany, Islamia College, Peshawar, in standard specimen bottles. The isolates were immediately preserved with neutral Lugol's Iodine solution, $0.5 \mathrm{ml}$ per $100 \mathrm{ml}$ water sample, and stored for a short time (Edler and Elbrächter 2010). The Lugol's iodine was prepared by dissolving $150 \mathrm{~g}$ potassium iodide and $50 \mathrm{~g}$ iodine in 980 $\mathrm{ml}$ distilled water, and then adding $20 \mathrm{ml}$ of glacial acetic acid. Water Quality Index (WQI) was used to classify the class and status of river. The 100-point index is divided into several ranges corresponding to the general descriptive terms. Physicochemical properties of the water from the sampling sites were measured using HANNA HI98190 portable meter and HANNA HI98703 meter in the laboratory.

\section{Results and discussion}

The current research work was carried out to find the diversity and distribution of the genus Spirogyra in different habitats of river Kabul. Out of all the filamentous green algae the genus found at all the three sites of river Kabul was Spirogyra. It was the most common genus of Chlorophyta found. A total of 37 species of Spirogyra were collected from 3 selected water sites of river Kabul (Table $1 \&$ Figure 2). From the collected samples of water 30 species of Spirogyra 
were found at unpolluted site of Shah Alam, 4 species at highly polluted site of gujar and
32 species at slightly polluted site of Khazana (Table 2).

Table 1. Occurrence of Spirogyra in the three (3) sites selected with water quality differences (Unpolluted, slightly polluted and highly polluted waters)

\begin{tabular}{|c|c|c|c|c|}
\hline \multirow{2}{*}{ S. No. } & \multirow{2}{*}{ Species } & \multicolumn{3}{|c|}{ Sites } \\
\hline & & $\mathbf{a}$ & $b$ & $c$ \\
\hline 1 & S. affinis & + & - & + \\
\hline 2 & S. circumlineata & + & - & + \\
\hline 3 & S. communis & + & - & - \\
\hline 4 & S. condensata & + & - & + \\
\hline 5 & S. conllinsii & + & - & + \\
\hline 6 & S. crassa & - & + & + \\
\hline 7 & S. daedaleoides & + & - & + \\
\hline 8 & S. deciminia & + & - & + \\
\hline 9 & S. denticulata & - & + & + \\
\hline 10 & S. dubia & + & + & + \\
\hline 11 & S. elongata & + & - & + \\
\hline 12 & S. fallax & - & - & + \\
\hline 13 & S. farlowii & - & - & + \\
\hline 14 & S. fluviatilis & + & - & + \\
\hline 15 & S. grevilleana & + & - & + \\
\hline 16 & S. fuellebornei & + & - & + \\
\hline 17 & S. gratiana & + & + & + \\
\hline 18 & S. juergensii & + & - & + \\
\hline 19 & S. jugalis & + & - & + \\
\hline 20 & S. longata & + & - & + \\
\hline 21 & S. majuscula & + & - & + \\
\hline 22 & S. micropunctata & + & - & + \\
\hline 23 & S. mirabilis & + & - & - \\
\hline 24 & S. nitida & + & - & + \\
\hline 25 & S. orientalis & + & - & - \\
\hline 26 & S. occidentalis & + & - & + \\
\hline 27 & S. pratensis & + & - & + \\
\hline 28 & S. proticalis. & + & - & + \\
\hline 29 & S. rectangularis & + & - & + \\
\hline 30 & S. parvula & + & - & + \\
\hline 31 & S. spreeiana & + & - & + \\
\hline 32 & S. scrobiculata. & + & - & + \\
\hline 33 & S. stictica & + & - & - \\
\hline 34 & S. subsalsa & - & - & + \\
\hline 35 & S. varians & - & - & + \\
\hline 36 & S. teodoresci & - & - & + \\
\hline 37 & S. weberii & - & - & + \\
\hline
\end{tabular}

Table 2. Percentage of occurrence of the species of Spirogyra at three selected sites

\begin{tabular}{|c|c|c|c|}
\hline S. No. & Selected Sites & No. of Species & Percentages \\
\hline 1 & Unpolluted & 30 & 81.1 \\
\hline 2 & Slightly polluted & 32 & 86.48 \\
\hline 3 & Highly polluted & 4 & 10.81 \\
\hline
\end{tabular}


The chemical analysis of water samples showed that the concentrations of $\mathrm{Caco} 3$ at unpolluted, highly polluted and slightly polluted sites were 164, 245 and 188mg/L respectively (Figure 3). Spirogyra was also a dominant genus in trems of species recorded by [18-20], stated that chlorophyceae is a major class with species, majority of which belong to genus Spirogyra the most common genus, which agree with our findings. Similarly [21-24], also reported Spirogyra a leading genus with speices which supports our present data. Spirogyra is the most frequent genus of freshwater green algae. The green, unbranched filaments of this genus occur in a wide variety of habitats, including lakes, rivers, streams, and temporary ponds [25-27].

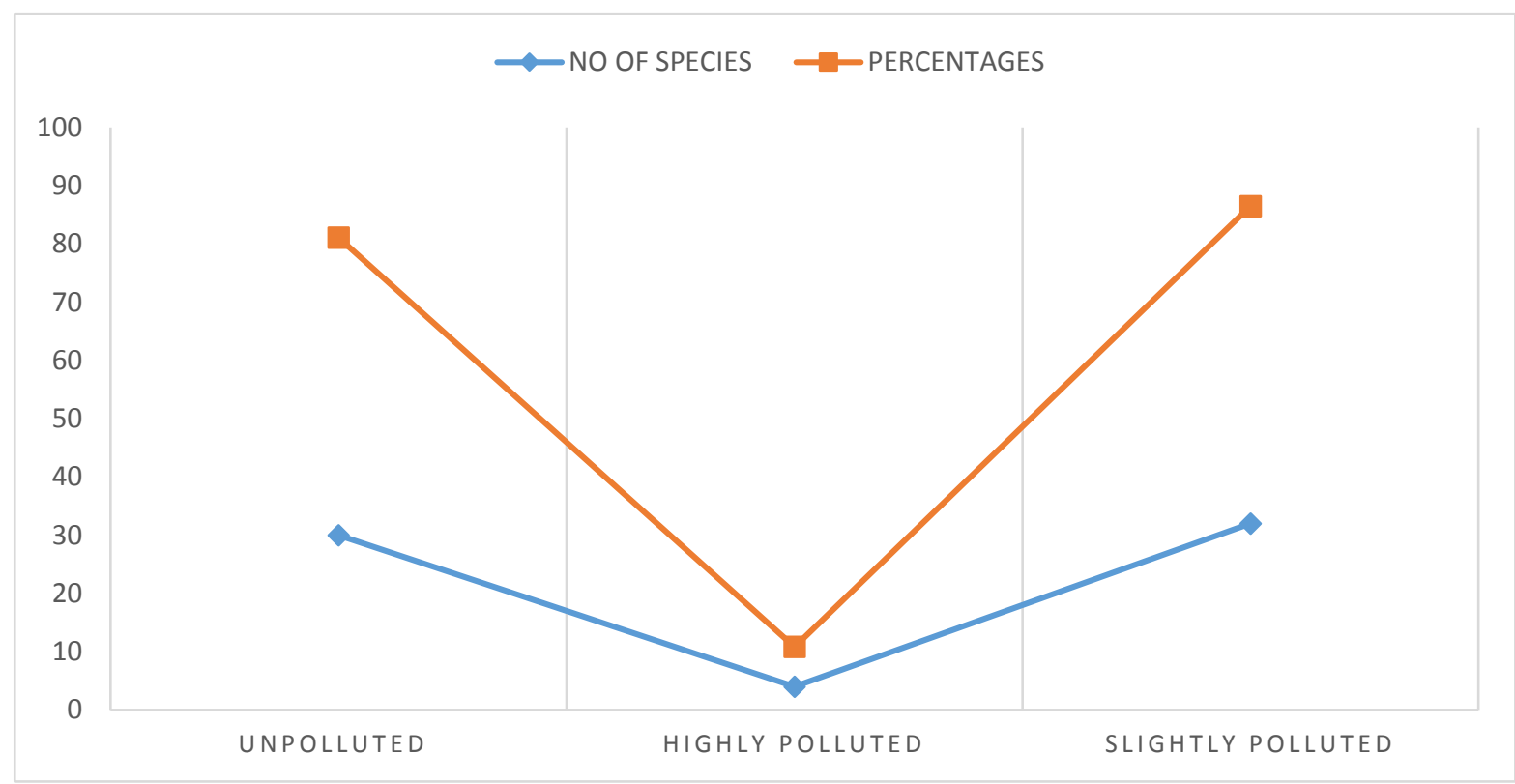

Figure 1. Number of species relation to sites chemical profile in the unpolluted, slightly and highly polluted waters

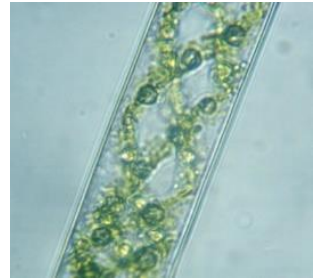

S. affinis

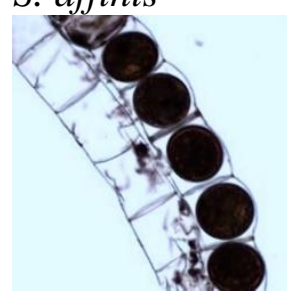

S. deciminia

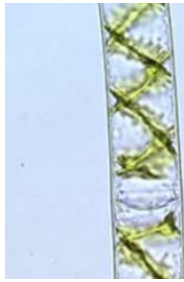

S. proticalis.

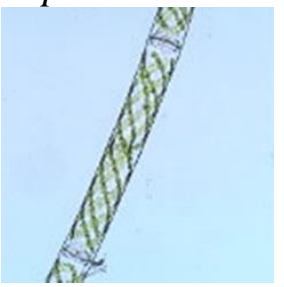

S. fallax

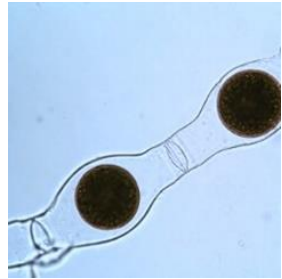

S. weberii

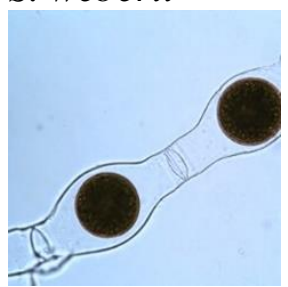

S. communis

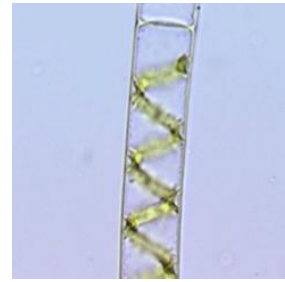

S. condensata

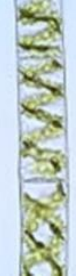

S. borgeana 


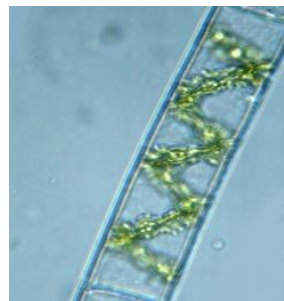

S. collinsii

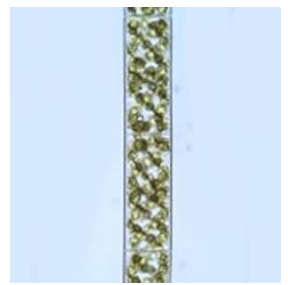

S. mirabilis

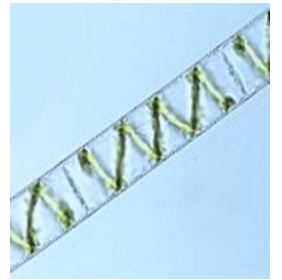

S. orientalis

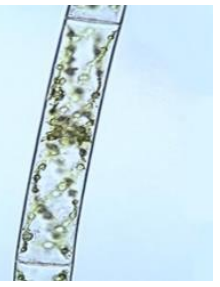

S. rectangularis

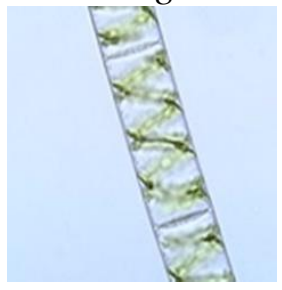

S. scrobiculata

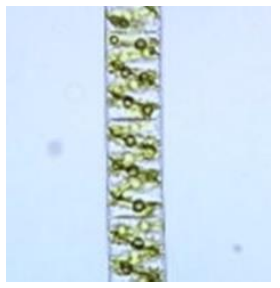

S.varians

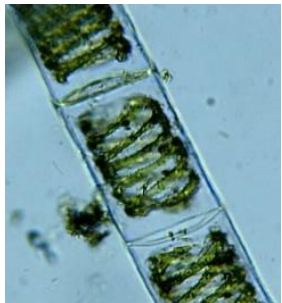

S. crassa

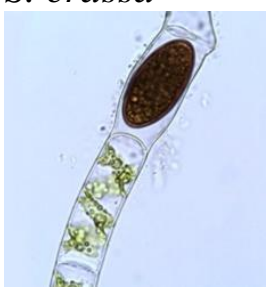

S. grevilleana

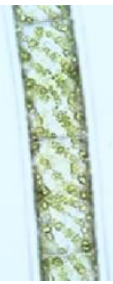

S. majuscula

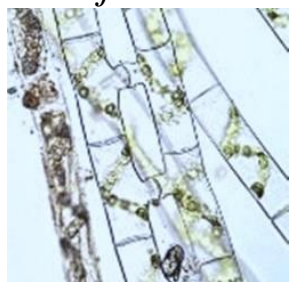

S. parvula

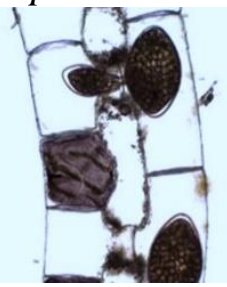

S. setiformis

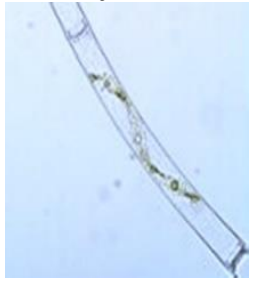

S. weberi

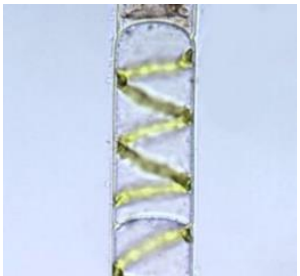

S. daedaleoides

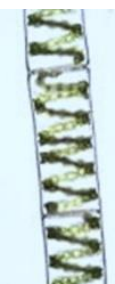

S. gratiana

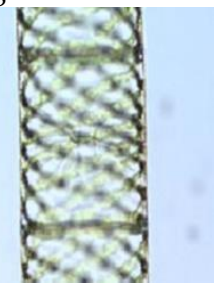

S. nitida

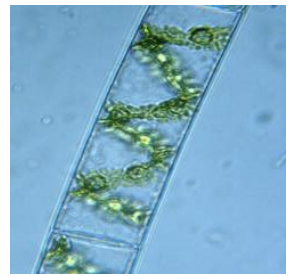

S. pratensis

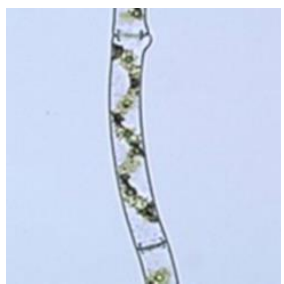

S. spreeiana

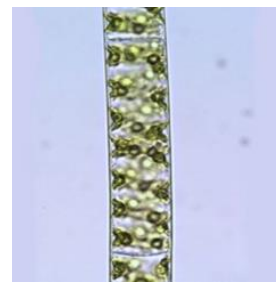

S. elongata

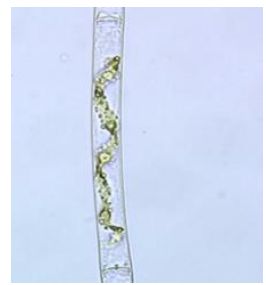

S. longata

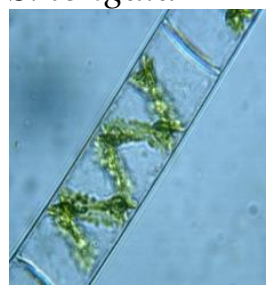

S. micropunctata

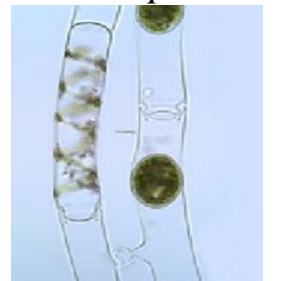

S. reflexa

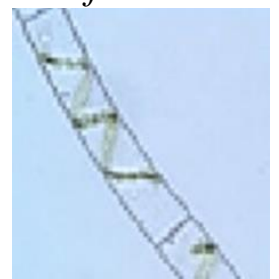

S. teodoresci

Figure 2. Pictures of the different species of Spirogyra identified from the research area 


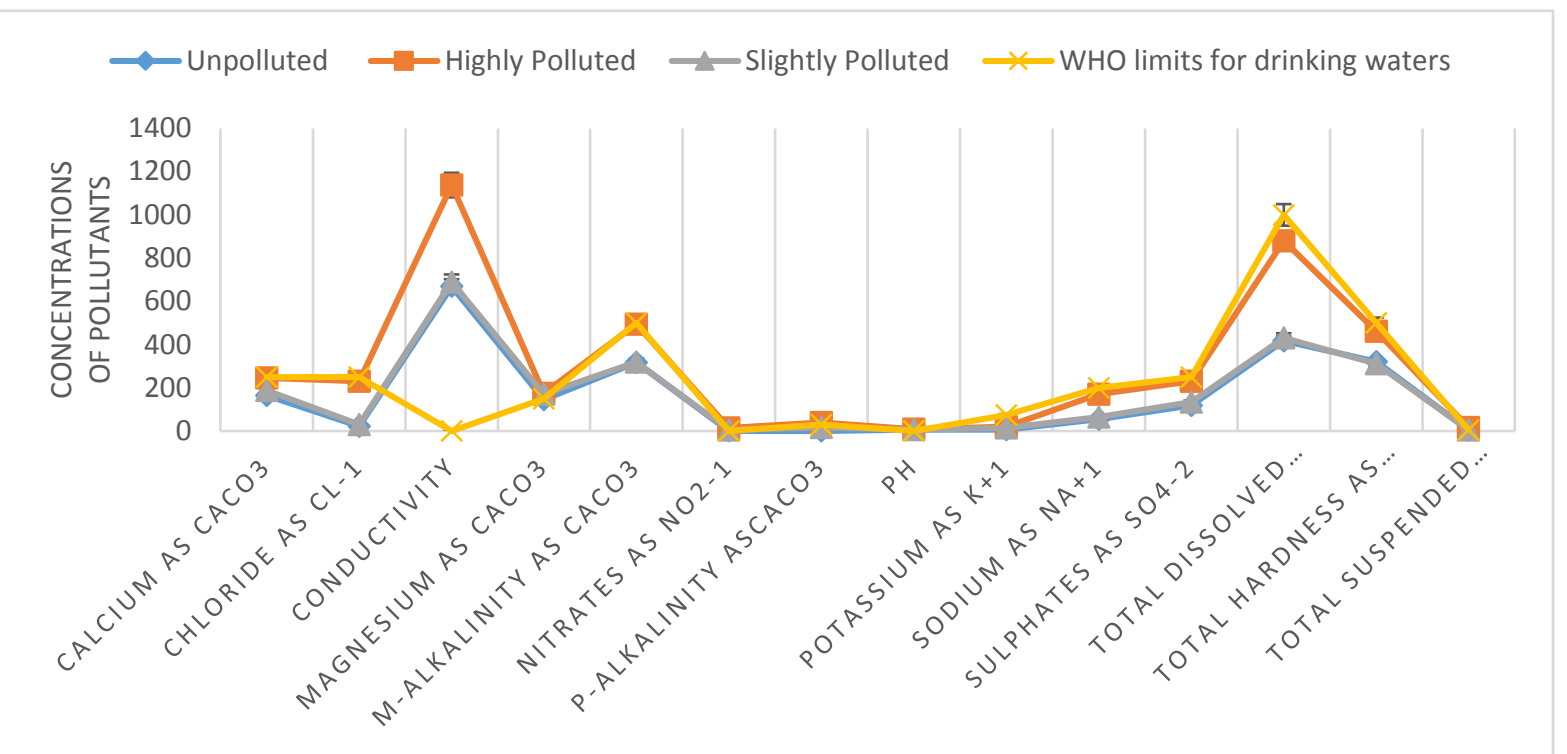

Figure 3. Analysis of the Chemical Components of the selected water samples in comparison to WHO standards

\section{Conclusion}

It was concluded in the current research work that Spirogyra has a wide distribution in the selected research sites. It is represented by a number of species. Similarly the distribution and diversity of the species in the genus Spirogyra in the research area is profundly affected by the habitat pollution levels i.e. unpolluted, slighlty polluted and highly polluted.

\section{Authors' contributions}

Conceived and designed the experiments: KRehman, S Wali \& I Khuram, Performed the experiments: $\mathrm{K}$ Rehman, $\mathrm{T}$ Yaseen \& $\mathrm{L}$ Farooq, Analyzed the data: S Wali, I Khuram, T Yaseen \& L Farooq, Contributed materials/ analysis/ tools: K Rehman, S Wali \& I Khuram, Wrote the paper: K Rehman, S Wali, I Khuram \& L Farooq.

\section{References}

1. Wood J (1872). A Journey to the Source of the River Oxus. J. Murray. London.

2. Gresswell RK \& Huxley AJ (1965). Standard encyclopedia of the world's rivers and lakes. New York, NY: GP. Putnam's Sons.

3. Khan SA \& Khan M (1997). Monitoring of water pollution in the Kabul River
(Pakistan) under low flow conditions. $J$ Chem Soc Pak 19(2).

4. Wilson EO (1988). The current state of biological diversity. Biodiver 521(1): 318.

5. Lubchenco J (1978) Plant species diversity in a marine intertidal community: importance of herbivore food preference and algal competitive abilities. The American Naturalist 112(983): 23-39.

6. Caumette G, Koch I \& Reimer K (2012). Arsenobetaine formation in plankton: a review of studies at the base of the aquatic food chain. $J$ of Environ Monitoring 14(11): 2841-2853.

7. Ansari AA, Gill SS \& Khan FA (2010). Eutrophication: threat to aquatic ecosystems, in Eutrophication: causes, consequences and control. Pollu and Remediation 143-170.

8. Bringmann G \& Kühn R (1980) Comparison of the toxicity thresholds of water pollutants to bacteria, algae, and protozoa in the cell multiplication inhibition test. Water Res 14(3): 231241. 
9. Shamshad I, Khan S, Waqas M, Ahmad N, Khushnood-Ur-Rehman \& Khan K (2015). Removal and bioaccumulation of heavy metals from aqueous solutions using freshwater algae. Water Sci and Technol 71(1): 38-44.

10. Sajida J, Jan S, Rehman K \& Hussain F (2013). Eco-taxonomic study of algal flora from Kurram River, Parachinar. Int J Phycol Phycochem 2013. 9(1): 63-68.

11. Alam A, Ullah S, Aftab S, Alam S, Khan Y, Rahman K \& Zahoor (2017). Evaluation of Sirogonium sticticum, Uronema elongatum, Chroococcus turgidus and Temnogyra reflexa for biodiesel production in Pakistan. Biofuels 8(3): 391-399.

12. Hutchinson GE (1961). The paradox of the plankton. The American Natur 95(882): 137-145.

13. Finlay BJ (2002). Global dispersal of free-living microbial eukaryote species. Sci 296(5570): 1061-1063.

14. Round FE (1984). The ecology of algae. CUP Archive.

15. Simons J \& Van-Beem A (1990). Spirogyra species and accompanying algae from pools and ditches in The Netherlands. Aquatic Bot 37(3): 247269.

16. Van Geel B (1976). Fossil spores of Zygnemataceae in ditches of a prehistoric settlement in Hoogkarspel (The Netherlands). Rev of Palaeobot and Palynol 22(4): 337-344.

17. Simons J \& Van Beem AP (1990). Spirogyra species and accompanying algae from pools and ditches in The Netherlands. Aquatic Bot 37(3): 247269.

18. Hardoim EL \& Heckman CW (1996). The Seasonal Succession of Biotic Communities in Wetlands of the Tropical Wet and Dry Climatic Zone: IV. The Free Living Sarcodines and Ciliates of the Pantanal of Mato Grosso, Brazil. Internationale Revue Der Gesamten Hydrobiol und Hydrographie 81(3): 367384.
19. Leake DV (1945). The algae of Crystal Lake, Cleveland County, Oklahoma. The American Midland Naturalist 34(3): 750-768.

20. Zidarova R (2008). Algae from Livingston Island (S Shetland Islands): a checklist. Phytologia Balcanica 14(1): 19.

21. Khuram I, Ahmad N, Jan S \& Barinova S. (2014) et al., Freshwater green algal biofouling of boats in the Kabul River, Pakistan. Oceanol and Hydrobiol Stu 43(4): 329-336.

22. Barinova S, Khuram I, Asadullah, Ahmad N, Jan S \& Shin DH (2016). How water quality in the Kabul River, Pakistan, can be determined with algal bio-indication. Adv Stu in Biol 8(4): 151171.

23. Khuram I, Barinova S, Ahmad N, Ullah A, Din S, Jan S \& Hamayun M (2017). Ecological assessment of water quality in the Kabul River, Pakistan, using statistical methods. Oceanol and Hydrobiol Stu 46(2): 140-153.

24. Khuram I, Muhammad Z, Ahmad N, Ullsh R \& Barinova S (2019) Green and charophyte algae in bioindication of water quality of the shah alam river (District Peshawar, Pakistan). Transylvanian Rev of Systematical and Ecol Res 21(1): 1-16.

25. Wali S, Yaseen T, Jan S, Ahmad I, Khan MS, Rahim F \& Noman (2017). Diversity of freshwater algae in some selected sites in river Naguman district Charsadda, Khyber Pakhtunkhwa, Pakistan. Pure Appl Biol 6(1): 180-189.

26. Lewis LA \& McCourt RM (2004). Green algae and the origin of land plants. American J of Bot 91(10): 1535-1556.

27. Wang JC, Hoshaw RW \& McCourt RM (1989). Diversity of Spirogyra (Chlorophyta) filament types on an altitudinal gradient. British Phycological J 24(4): 367-373. 